GETTING TO WE 


\title{
GETTING TO WE
}

\section{Negotiating Agreements for Highly Collaborative Relationships}

\author{
Jeanette Nyden, Kate Vitasek, and \\ David Frydlinger
}


All rights reserved.

First published in 2013 by

PALGRAVE MACMILLAN ${ }^{\circledR}$

in the United States-a division of St. Martin's Press LLC,

175 Fifth Avenue, New York, NY 10010.

Where this book is distributed in the UK, Europe and the rest of the world, this is by Palgrave Macmillan, a division of Macmillan Publishers Limited, registered in England, company number 785998, of Houndmills, Basingstoke, Hampshire RG21 6XS.

Palgrave Macmillan is the global academic imprint of the above companies and has companies and representatives throughout the world.

Palgrave ${ }^{\circledR}$ and Macmillan ${ }^{\circledR}$ are registered trademarks in the United States, the United Kingdom, Europe and other countries.

ISBN 978-1-137-60283-1

DOI $10.1057 / 9781137344151$

ISBN 978-1-137-34415-1 (eBook)

Library of Congress Cataloging-in-Publication Data

Nyden, Jeanette.

Getting to we : negotiating agreements for highly collaborative relationships / Jeanette Nyden, Kate Vitasek, and David Frydlinger. pages $\mathrm{cm}$

Includes bibliographical references and index.

ISBN 978-1-137-29718-1 (alk. paper)

1. Negotiation in business. 2. Interpersonal relations. 3. Organizational behavior. I. Vitasek, Kate. II. Frydlinger, David. III. Title.

HD58.6.N93 2013

$658.4^{\prime} 052$-dc23

A catalogue record of the book is available from the British Library.

Design by Newgen Imaging Systems (P) Ltd., Chennai, India.

First edition: August 2013

1098776543321 


\section{DEDICATION}

We would like to dedicate this book to our partners, who selflessly give us their time, support, and encouragement. Together, we live the principles embodied by Getting to We each day.

Tim, Greg, and Caroline: we are in your debt and appreciate all you have done for us.

Tim Lohraff (husband) and Isabella and Elizabeth Lohraff Jeanette Nyden Greg Picinich (husband) and Austin Picinich Kate Vitasek

Caroline Frydlinger (wife) and Rebecka, Oskar and Klara David Frydlinger 


\section{CONTENTS}

List of Figures

Introduction 1

Chapter 1. What Are You G-e-t-t-i-n-g To? 7

\section{SECTION I}

STEP 1: ESTABLISH A FOUNDATION OF

TRUST, TRANSPARENCY, AND COMPATIBILITY

Chapter 2. Trust

Chapter 3. Transparency and Compatibility

SECTION II

A SHARED VISION AND COMMON GUIDING PRINCIPLES

Chapter 4. Step 2: Creating a Shared Vision

Chapter 5. Step 3: Establishing the Six Essential

SECTION III

STEP 4: NEGOTIATING AS WE

Chapter 6. Four Rules for Collaborative Negotiations

Chapter 7. WIIFWe Styles, Strategies, and Tactics

Chapter 8. Negotiating Money for Mutual Benefit

\section{SECTION IV \\ LIVING AS WE}

Chapter 9. Step 5: Relationship Management

Chapter 10. The Power of We

Conclusion We Are All Winners 
Notes

Index 


\section{FIGURES}

3.1 Comparison of P\&G and Jones Lang LaSalle corporate cultures $\quad 51$

3.2 Value Map $\quad 54$

3.3 Spider graphic: Low gaps $\quad 56$

3.4 Spider graphic: High gaps $\quad 57$

$\begin{array}{lll}7.1 & \text { We and Me strategies } & 140\end{array}$

7.2 Initiating the relationship among multiple parties 142

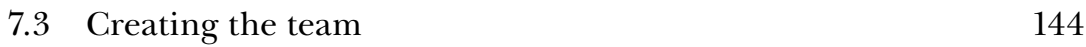

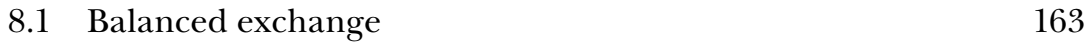

$\begin{array}{ll}8.2 \text { Unbalanced exchange } & 164\end{array}$

8.3 Value exchanges $\quad 165$

8.4 Rocky Flats Closure Project pricing model 176

$\begin{array}{lll}9.1 & \text { Global relationship management } & 198\end{array}$

$\begin{array}{lll}9.2 & \text { Escalation process } & 204\end{array}$ 